\title{
COMPULSORY LICENSING AND ACCESS TO MEDICINES IN POST DOHA ERA: WHAT HOPE FOR AFRICA?
}

\author{
by Ebenezer Durojaye*
}

1. Introduction

2. Access to medicines as a human right

3. Events preceding the Doha Declaration

3.1 The Doha Declaration

4. Compulsory licensing after Doha

4.1 Origin of compulsory licensing

4.1.1 Grounds for use of compulsory licensing

4.1.2 Limitation under Article 31(f) TRIPS

4.2 The August 2003 Decision of the Council for TRIPS and its implications

4.3 The 6 December 2005 amendment of the TRIPS Agreement

4.4 The Zimbabwean experience

4.5 Exploring alternatives for African countries

4.5.1 Article 31(k) TRIPS

5. Some developments in the use of compulsory licensing

6. Human rights and intellectual property rights

7. Conclusion

* LLB (Lagos), LLM (specialising in Sexual and Reproductive Rights, Free State), LLD (candidate Free State); Research Assistant, Department of Constitutional Law and Philosophy, Faculty of Law, University of the Free State, South Africa. Email durojayeet.rd@ufs.ac.za. The author is grateful to Professor Charles Ngwena of the Faculty of Law at the University of the Free State for his guidance and direction during the preparation of this article. Thanks equally go to my colleague Thapi Matsaneng for her comments on the earlier draft of the article. 


\section{INTRODUCTION}

'Globally trade policy provisions need to be used more effectively to increase access to care. The availability of low-cost generic drugs needs to be expanded, in accordance with national laws and international trade agreements and with a guarantee of their quality ... We need to find ways of more effectively using trade policy provisions, such as compulsory licensing or parallel importation, to increase access to care. The availability of low-cost generic drugs needs to be expanded, in accordance with national laws and international trade agreements and with guarantees of their quality.'

The Trade Related Aspects of Intellectual Property Rights (TRIPS) Agreement of 1994, an outcome of the Uruguay Round negotiations, radically altered the role of international trade law in promoting and enforcing intellectual property protection around the globe. ${ }^{2}$ This important, yet controversial, international agreement requires members of the World Trade Organization (WTO) to implement strong intellectual property protections in their domestic law. Indeed the emergence of the TRIPS Agreement at the end of deliberations in Marrakesh has been described as a major tactical victory for rich countries and pharmaceutical companies. ${ }^{3}$ Prior to 1994 , countries of the world were not obligated to grant patent rights for pharmaceutical products, but with the signing of the TRIPS Agreement this changed. Along with this change, patent protection for pharmaceuticals, and the impact such patent protection is likely to have on access to medicines for the world's poor, have become a major source of conflict between rich and poor nations.

African countries remain particularly worst affected by this development. This is a continent that is grappling with various problems including poverty, conflicts and devastating diseases such as HIV/AIDS, tuberculosis and malaria. While Africa constitutes about ten percent of the world's population it is home to over 70 percent of people living with HIV. In 2006 alone, approximately three million people were reported to have lost their lives as a result of HIV/ AIDS related illness, 70 percent of which were from sub-Sahara Africa. ${ }^{4}$ Women have been the worst affected by the epidemic, constituting about 50 percent of the world infection rate and about 60 percent of the total rate in Africa. ${ }^{5}$ In many African countries, access to treatment and care for people

1. Report of the UN Secretary General to the UN General Assembly meeting issued on 16 February 2001, UN Doc. A/55/779.

2. The TRIPS Agreement was part of the Final Act establishing the WTO commonly referred to as the 'Marrakech Agreement', attached as Annex 1C to the WTO Agreement.

3. See M.A. Santoro, 'Human Rights and Human Needs: Diverse Moral Principles Justifying Third World Access to Affordable HIV/AIDS Drugs', 31 North Carolina Journal of International Law and Commercial Regulation (2006) p. 923 at p. 926.

4. UNAIDS, Report on the Global AIDS Epidemic (Geneva, UNAIDS 2006) p. 6.

5. Ibid. 
living with HIV remains a great challenge. Of the approximately 4.6 million people in need of treatment, only about 23 per cent of them are receiving it in the region. ${ }^{6}$ The problem is not limited to HIV/AIDS alone. Other diseases such as tuberculosis and malaria continue to pose great threats to lives in Africa.

It is recognised that the TRIPS Agreement contains some safeguard provisions, such as parallel imports, early working exception and compulsory licensing, which African countries can explore to ensure access to life-saving medications for their citizens. However, implementation of these provisions in practice has not been as easy as expected. Attempts at invoking these flexibility provisions under TRIPS, especially compulsory licensing, have often met with stiff opposition from developed countries and pharmaceutical companies. Compulsory licensing is a license issued by a state authority to a government agency, a company or other party to use a patent without the patent holder's consent. Usually royalty is paid to the patent holder as a form of compensation for the use of its patent. It is very crucial and can play a great role in ensuring access to life-saving medications for people living with HIV in developing countries. It must be noted that a denial of access to life-saving medications is a human rights issue, as it may have direct implications on the enjoyment of an individual's rights to health and life guaranteed in numerous human rights instruments. The right to life is the most fundamental of all human rights that must be held in great sanctity. ${ }^{7}$ On the other hand, the right to health relates to both physical and mental well-being of an individual. These rights are negatively threatened due to inaccessibility to life-saving drugs in Africa.

One needs to point out here that recent developments in the world seem to show that cheaper drugs are being made available in developing countries due to a series of international initiatives and support from developed countries such as the Global Fund and the United States (US) government's President Emergency Plan Fund for AIDS Relief (PEPFAR). More importantly, one must commend the initiatives and efforts of the Clinton Foundation for being able to strike some deals with pharmaceutical companies to sell HIV/AIDS drugs at a cheaper price in some developing countries. ${ }^{8}$ However, drugs made available under these initiatives are reaching very few people. There are better opportunities for developing countries to scale up treatment for their citizens if they are allowed to effectively invoke the flexibility provisions contained in the TRIPS Agreement particularly compulsory licensing. But with limited resources and high cost of drugs, particularly for second-line drugs for HIV/AIDS treatment, just a handful of people can at present be reached.

6. Ibid.

7. Human Rights Committee, The Right to Life, UN GAOR, 37th Sess., Supp. No. 40.

8. See L. Altman, 'Clinton Group Gets Discount for AIDS Drugs', New York Times, 24 October 2003, p. 1, where it was reported that the Foundation has struck a deal with some pharmaceutical companies to sell ARVs at cheaper prices in some countries in Africa and the Caribbean. 
It is against this backdrop that this article examines the importance of compulsory licensing - using a human rights lens - to facilitate access to lifesaving medications for Africans and its use after the historic decision at Doha in 2001 (popularly called 'Doha Declaration'). It further considers the August 2003 Decision of the Council for TRIPS and the subsequent December 2005 amendment of the TRIPS Agreement in an attempt to resolve paragraph 6 of Doha Declaration and submits that both are neither faithful to the spirit of Doha nor are they in line with provisions of human rights instruments, which guarantee the rights to health and life. Also, the article reasons that recent developments in the world on the use of compulsory licensing, such as the new Canadian legislation on this issue, have not in any way brought succor to Africans. The article further argues that in view of the above situations, particularly the failure of both the August 2003 Decision of Council for TRIPS and its amendment of TRIPS Agreement to find a lasting solution to the unresolved paragraph 6 of Doha, African countries may need to be creative in invoking other provisions of the TRIPS, such as Article 31(k) so as to ensure affordable medicines for their citizens. The article then considers the likely tension that may exist between human rights and intellectual property rights, and submits that the obligations of states under the former should supercede the latter.

\section{ACCESS TO MEDICINES AS A HUMAN RIGHT}

The TRIPS Agreement most significantly has serious implications for access to life-saving medications in Africa. Access to treatment forms an integral part of the right to health guaranteed in so many international human rights instruments. Notable among these instruments include Article 25 of the Universal Declaration on Human Rights (UDHR), ${ }^{9}$ Article 12 of the International Covenant on Economic, Social and Cultural Rights (ICESCR), ${ }^{10}$ Article 12, of the Convention on Elimination of All Forms of Discrimination against Women (CEDAW), ${ }^{11}$ Article 16 of the African Charter on Human and Peoples' Rights (African Charter), ${ }^{12}$ just to mention a few. However, the most authoritative of these instruments is Article 12 of ICESCR, which guarantees the right to the highest attainable standard of health to every one. It similarly recognises the

9. Universal Declaration of Human Rights, GA Res. 217 A (III), UN Doc. A/810 (10 December 1948).

10. International Covenant on Economic, Social and Cultural Rights, adopted 16 December 1966, GA Res. 2200 (XXI), UN Doc. A/6316 (1966), 993 UNTS p. 3 (entered into force 3 January 1976).

11. Convention on Elimination of All Forms of Discrimination Against Women, GA Res. 54/180, UN GAOR, 34th Session, Supp. No. 46, UN Doc. A/34/46 (1980).

12. African Charter on Human and Peoples' Rights, OAU Doc. CAB/LEG/67/3/Rev.5; adopted by the Organization of African Unity, 27 June 1981, entered into force 21 October 1986. 
importance of other determinants of health such as clean water, clean environment and so on to the enjoyment of this right.

The Committee on the Covenant on Economic Social and Cultural Rights (CESCR) in its General Comment 14 has noted that the basic elements of the right to health include availability, accessibility, acceptability and quality. ${ }^{13}$ Access to medicines requires that such medicines must be accessible and affordable. The Committee has similarly noted that economic accessibility or affordability presupposes that health facilities, goods and services must be affordable to all. ${ }^{14}$ It notes further that payment for health-care services, as well as services related to the underlying determinants of health (including drugs), must be based on the principle of equity, which demands that "poorer households should not be disproportionately burdened with health expenses as compared to richer households' ${ }^{15}$ Ensuring access to health facilities especially for marginalised groups constitutes one of the core obligations of the right to health. ${ }^{16}$ It is to be noted that states are obligated to respect, protect and fulfill the right to health. The implication of these obligations vis-à-vis obligations under intellectual property law is considered later in another section of this article.

Inability of Africans to have access to life-saving medications in the context of life threatening diseases, such as HIV/AIDS, tuberculosis and malaria, compromises their right to health. Heywood has noted that 'breakthroughs in some crucial areas of medicine and paralysis in others, place unparalleled importance on access to drugs as part of the right to health' ${ }^{17}$ Lack of access to medicines may similarly implicate on the right to life. Since the enjoyment of the right to health is dependent on other rights such as human dignity, freedom of association, right to housing, right to life, etc. ${ }^{18}$ This is an affirmation of the interrelatedness, interdependence and indivisibility of all human rights - civil and political and social and economic rights - as pronounced at the Vienna Programme of Action. ${ }^{19}$

Traditionally, the right to life is viewed as a negative right to prevent intentional loss of lives. However, recent developments now view the right to life as a positive right placing an obligation on states to protect unintentional loss of lives..$^{20}$ For instance, the Inter-American Court of Human Rights has held

13. UN Committee on Economic, Social and Cultural Rights, The Right to the Highest Attainable Standard of Health, General Comment No. 14, UN Doc. E/C.12/2000/4, para. 12.

14. Ibid.

15. Ibid.

16. Ibid., para. 43.

17. M. Heywood, 'Chaffed and Waxed Sufficient: Drug, Access, Patent and Global Health', 23 Third World Quarterly (2002) p. 217 at p. 218.

18. General Comment 14, supra n. 13, para. 3.

19. Vienna Programme of Action, UN Doc. A/CONF.157/24, Part 1, Chap. III.

20. R.J. Cook, et al., Reproductive Health and Human Rights Integrating Medicine, Ethics and Law (Oxford, Clarendon Press 2003) p. 161. 
that the government of Guatemala was responsible for loss of life arising from shabby treatment meted out to street children. In arriving at its decision the Court noted as follows:

'The fundamental right to life includes not only the right of every human being not to be deprived of his/her life arbitrarily but also the right that he/she will not be prevented from having access to conditions that guarantee a dignified existence. ${ }^{21}$

Also, the Supreme Court in Costa Rica has held that a denial of access to lifesaving medication for people infected with HIV impugns on their right to life. ${ }^{22}$

Regarding access to life-saving medications, Yamin has pointed out that given the indispensability of these drugs to life, any policy by the state, which may diminish physical accessibility and affordability to them will ultimately deprive people of their right to life. ${ }^{23}$ The Human Rights Committee in its Comment 6 on Article 6 of the International Covenant on Civil and Political Rights (ICCPR) has suggested that the right to life in Article 6 of the Covenant should not be given a narrow interpretation but should be seen to affect other rights such as the rights to housing, food and medical care. ${ }^{24}$

\section{EVENTS PRECEDING THE DOHA DECLARATION}

At the start of the new millennium, the impact of TRIPS was beginning to be felt by developing countries, particularly Africa, just as the devastating effect of the HIV/AIDS pandemic deepened. Prices of life-saving medicines were no longer within the reach of the people even as they became more urgently indispensable to preserve lives. In Nigeria, for instance, prices of antiretroviral drugs (ARVs) during that period ranged between 100 to 200 US dollars monthly. ${ }^{25}$ This is inaccessibly high for a country where the majority of citizens live on less than one dollar a day. Many of the developing countries blamed the TRIPS Agreement for being a barrier to life-saving medications. They argued that patent rights on drugs lead to monopoly and precipitated prohibitive cost of

21. Villagran Marales et al v. Guatemala, Series C No. 65, 19 November 1999, para. 144; see also The Social and Economic Rights Action Centre and the Centre for Economic and Social Rights v. Nigeria, Communication 155/96, decided at the African Commission's Ordinary Session held from 1 to 27 October 2001; similarly see the Indian Supreme Court decision in Pachim Banga Khet Majoor Samity v. State of West Bangal [1996] AIR SC 2426.

22. Alvarez, v. Ccaja Costarricense de Seguro Social Exp, 5778-V-97, No. 5934-97, cited by A.E. Yamin, 'Not Just a Tragedy: Access to Medication as a Right under International Law', 21 Boston Univ. ILJ (2003) p. 326.

23. Yamin, supra n. 22, at p. 326.

24. Human Rights Committee, The Right to Life, supra n. 7.

25. K. Peterson and O. Obileye, Access to Drugs for HIV/AIDS and Related Opportunistic Infections in Nigeria (Abuja, Policy Project 2002) p. 13. 
drugs. Furthermore, they reject as flimsy and baseless the need to compensate invention and promote research and development as justifications for patent on drugs, asserting that cost of research and development in a country like the US, which is home to many of the pharmaceutical companies, is borne by public institutions. ${ }^{26}$ Crucially, it is noted that Africa accounts for only one percent of world's medicine market and if there were no patent protection in Africa and no sales by pharmaceutical companies their profits from drugs will by no means be affected. ${ }^{27}$

Pharmaceutical companies have, however, insisted that unless there is an incentive for research and development in the name of patents, new drugs may not be discovered. They reject the argument that patent hinders access to medicines in developing countries but rather cite poor infrastructure, poor distribution system, coupled with low morale of health workers due to poor salaries as obstacles to access to medicines in developing countries. ${ }^{28}$ But the truth remains that patent rights inhibit access to essential medicines in Africa and other poor regions of world. ${ }^{29}$ This is most pronounced in the case of lifesaving medications particularly for HIV/AIDS where demands for such drugs are usually inelastic. In a situation as this, higher prices do not diminish demand for these drugs, as they remain essential regardless of high prices. ${ }^{30}$

The essence of intellectual property rights, and in particular patent, is to provide necessary incentives for research and technological development. Patents are said to be time-bound monopoly rights, which constitute a derogation from the principle of free trade because they offer exclusive rights to an inventor to exploit the invention and prevent others from using same without his/her consent. ${ }^{31}$

There are two basic reasons, which have been adduced to justify the need for protection of intellectual property rights. One has to do with the theory of fair compensation while the other relates to incentives to encourage invention. ${ }^{32}$ The

26. M. Foreman, et al., Beyond Our Means? The Cost of Treating HIV/AIDS in the Developing Countries (London, Panos Institute 2000) p. 1.

27. P. Boulet, et al., Drug Patents under the Spotlight: Sharing Practical Knowledge about Pharmaceutical Patents (Geneva, MSF 2003) p. 6.

28. International Intellectual Property Institute (IIPI), Patent Protection and Access to HIV/ AIDS Pharmaceuticals in Sub-Sahara Africa (Washington, DC, IIPI 2000) p. 24.

29. See Commission on Intellectual Property Rights (independent commission set up by Brit-

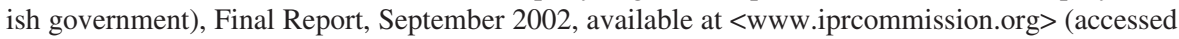
on 29 September 2007). The report finds intellectual property rights impose costs on most developing countries and do not help to reduce poverty.

30. E. Cameron, 'Patents and Public Health: Principles, Politics and Paradox', a paper delivered at the Inaugural British Academy Law Lecture held at University of Edinburgh on 19 October 2004.

31. P. Cullet, 'Patents and Medicines: The Relationship between TRIPS and Human Rights to Health', 79 International Affairs (2003) p. 140.

32. J. Trebilcock and R. Howse, The Regulation of International Trade, 2nd edn. (London, Routledge 1999) p. 32. 
theory of fair compensation is based on Locke's labour theory of property. This theory asserts that one owns the fruits of one's labour. ${ }^{33}$ In other words, this theory seems to equate intellectual property with other property such as land, and asserts that an inventor must be fairly compensated for time and energy invested in his/her invention. However, this argument has been criticised in the sense that it limits present access to products so as to encourage future development of new products to which, ironically, access is also limited. ${ }^{34}$ Furthermore, this theory is subject to two qualifications. One is that it will only suffice for as long as the society is not left worse off by reason of one's appropriation. ${ }^{35}$ In this situation there is no objection to benefiting from fruits of one's labour. Hettinger has, however, observed that patent runs foul of this qualification since people who come up with same invention as one already patented are restricted from selling or even using their inventions. ${ }^{36}$ The other is that acquisition of property rights must not be subject to prohibition from spoilage. ${ }^{37}$ That is, appropriations of property should avoid unnecessary wastefulness. Also, it would appear intellectual property rights contradict this proviso in the sense that full exercise of rights in intellectual property limits certain beneficial uses of the protected products. ${ }^{38}$

The second theory supporting the need for intellectual property rights asserts that little incentives to innovate exist where people are allowed to be rewarded for their inventions at little or no cost. This is known as the so-called 'free rider' problem. The argument here is that without appropriate protection for intellectual property rights there will be no motivation to innovate. While it is possible that intellectual property protection could encourage innovation, it has been disputed that strong intellectual property rights 'increase the availability and use of intellectual products more than they restrict this availability and use'. 39 A report has further disproved this point noting that in poor regions most affected by diseases where limited purchasing power exists, patents are not a relevant factor in stimulating research and development or bringing new products into the market. ${ }^{40}$ Indeed, Berger argues that little evidence exists to support the

33. R.E. Meiners and R.J. Staaf, 'Patents, Copyrights, and Trademarks: Property or Monopoly?', 13 Harvard Journal of Law and Public Policy (1990) p. 911 at p. 915.

34. Cameron, supra n. 30.

35. E.C. Hettinger, 'Justifying Intellectual Property', 18 Philosophy and Public Affair (1989) p. 31 at p. 35 .

36. Ibid.

37. J. Locke, 'The Second Treaties of Government', in P. Laslet, ed., An Essay Concerning the True Original, Extent, and End of Civil Government (Cambridge, University Press 1988) p. 308.

38. J.M. Berger, 'Tripping over Patents: AIDS, Access to Treatment and the Manufacturing of Scarcity', 17 Connecticut JIL (2002) p. 157 at p. 173.

39. Hettinger, supra n. 35.

40. See WHO Commission on Intellectual Property Rights, 'Innovation and Public Health, Framework paper', July 2006, available at <www.who.int/intellectualproperty/documents/thereport/ CIPIH23032006.pdf> (accessed on 1 October 2007). 
hypothesis that extended period of intellectual property protection promotes innovation. ${ }^{41} \mathrm{On}$ the contrary, it has been suggested that innovation is fuelled by 'looming expiration' of intellectual property protection. ${ }^{42}$

Efforts made by developing countries, during this period, to ensure access to medicines for their people by invoking the flexibility provisions were opposed by pharmaceutical companies. Specific situations related to that of Thailand, Brazil and South Africa. Under the Brazilian patent law, Article 68 permits the use of compulsory licensing. ${ }^{43} \mathrm{~A}$ threat by the Brazilian government to invoke this law to ensure access to HIV/AIDS medications for her citizens incurred the wrath of America, which filed a petition before the WTO panel opposing the action of the Brazilian government. This petition was later withdrawn, by which time the Brazilian government through its threat, had forced pharmaceutical companies to reduce prices of patented HIV/AIDS drugs in that country.

Also, worthy of mention was the court action instituted by about 39 pharmaceutical companies against the South African government for enacting a new patent law in 1997. ${ }^{44}$ The court action filed at a Pretoria High Court challenged sections $15 \mathrm{C}$ and $22 \mathrm{C}$ of the law that permit the South African government to use both parallel importation and compulsory licensing respectively in the wake of the HIV/AIDS pandemic in the country. ${ }^{45}$ The pharmaceutical companies, backed by America, claimed that the new law contravened the TRIPS Agreement and the Constitution of South Africa 1996. A determined South African government had insisted that its action was never inconsistent with the TRIPS Agreement. However, a fierce campaign by civil society groups and non-governmental organizations (NGOs) across the globe led to the withdrawal of the suit from court by the pharmaceutical companies, by which time the event had led to a public relation disaster for the pharmaceutical companies. There were two major fallouts of this case. First, it provoked a clarification to the so-called flexibility of the TRIPS Agreement especially as regards public health. Second, it clearly brought to the fore the fact that developed countries that exercised trade pressures in order to safeguard interests of pharmaceutical companies could no longer do so without some repercussions even within their territory. ${ }^{46}$

41. Berger, supra n. 38, at p. 173.

42. A.B. Engelberg, 'Special Patent Provision for Pharmaceuticals: Have They Outlived Their Usefulness? A Political, Legislative and Legal History of US Law and Observation for the Future', 39 Idea (1999) p. 389 at p. 421.

43. Industrial Property Law Act No. 23 (1998), which provides: 'A patent owner shall be subject to the grant of compulsory licence of his patent if the rights resulting therefrom are exercised in an abusive manner or if the patent is used in abused of economic power, as proven by an administrative or judicial decision pursuant to the provisions of the law.'

44. See Medicines and Related Substances Control Amendment Act No. 90 (1997).

45. Pharmaceutical Manufacturers' Association of South Africa v. President of the Republic of South Africa, Case No. 4183/98 (filed 18 February 1998) (HC).

46. E. 't Hoen, 'TRIPS, Pharmaceutical Patents and Access to Essential Medicines', 3 Chicago JIL (2002) p. 31. 
Although this case was withdrawn from court, it would have been interesting to know the outcome had the court the opportunity to decide on the merits of the case taking into consideration Section 25 of the South African Constitution of 1996. This Section of the Constitution guarantees the right to property. It further provides that in the event of expropriation of a property by the government "just and equitable compensation' must be paid to the owner of the property. ${ }^{47}$ It must be stated here that it remains uncertain whether an invocation of compulsory licensing to override patent rights under the South African Constitution will amount to an expropriation. ${ }^{48}$ But assuming it does, what is the implication of this? The logical answer will be that patent holders will be entitled to compensation in accordance with the provision of the Constitution.

However, certain factors such as the use of property, history of acquisition, nature of state investment in the acquisition, purpose of acquisition and so on must be taken into consideration by the court to determine the nature of compensation. In other words, if the property has been used to the detriment of the society, for instance, if it is found that prices of patent drugs in South Africa are higher than in other comparable countries, then the compensation payable will be below market value. ${ }^{49}$ Also, if the purpose for the overriding of patent right is to ensure access to cheaper life-saving medication, reason demands that the compensation payable to the patent holder by generic manufacturer should be minimal. Otherwise, the purpose for the issuance of the license in the first place will be defeated.

Other notable events which took place before Doha included the consistent and coordinated activities of NGOs in Africa and internationally. These organizations, such as Médecins Sans Frontières (MSF), ACT UP and Oxfam, were able to foster a formidable coalition pressing for affordable access to medications in poor countries of the world, particularly in the light of the HIV/AIDS pandemic in sub-Sahara Africa. In furtherance of their cause, an international conference on Increasing Access to Medicines in a Global Economy was held in Amsterdam in 1999, just a few days before the Seattle WTO ministerial meeting. ${ }^{50}$ Of great importance was a statement issued at the end of the Amsterdam meeting which raised concerns about the impact of trade policies on public health particularly access to HIV/AIDS medications in developing countries.

At the 1999 WTO ministerial meeting in Seattle, the impact of TRIPS on public health was not considered. However, a common working paper which contained a proposal 'to issue compulsory licensing for drugs appearing on the lists of essential drugs of the World Health Organization (WHO)' was devel-

47. See Section 25(3) of the South African Constitution Act No. 108 (1996).

48. Berger, supra n. 38, at p. 210.

49. Ibid.

50. 't Hoen, supra n. 46, at p. 32. 
oped. ${ }^{51}$ It has been argued that if this proposal had been accepted, it would have restricted the use of compulsory licensing in developing countries since very few of the drugs on the WHO lists of essential drugs were patented. ${ }^{52}$ But an important incident took place at the Seattle meeting. A formal statement was issued by President Bill Clinton of the US to the effect that 'the United States will henceforward implement its health care and trade policies in a manner that ensures that people in the poorest countries won't have to go without medicines they so desperately need'. ${ }^{53}$ This statement was later to be followed by an executive statement in 2000 confirming this change in US policy. ${ }^{54}$ However, subsequent actions taken by America in relation to the use of the flexibility in the TRIPS have proved inconsistent with this statement. Some of these actions are discussed in relevant parts of this article.

During this period two important meetings took place. One was the United Nations (UN) General Assembly Special Session on HIV/AIDS known as the Declaration of Commitment. ${ }^{55}$ The other was the Abuja Declaration on HIV/ AIDS and other related diseases by African leaders. ${ }^{56}$ These two important gatherings added powerful voices to the clamour for access to essential medicines in particular HIV/AIDS medications for poor countries. Both conferences recognised the public health threat posed by the HIV pandemic and urged states to mobilize resources in addressing urgently the epidemic and provide necessary treatment care and support for those already infected.

Furthermore, the activities of UN bodies and international agencies such as the WHO, the Joint United Nations Programme on HIV/AIDS (UNAIDS), the United Nations Development Programme (UNDP), the World Bank, etc., added more weight to the clamour for access to essential medicines in developing countries in post TRIPS era. Notable among these included the United Nations Commission on Human Rights adopted Resolution 2001/33, on Access to Medication in the Context of Pandemics such as HIV/AIDS of April 2001, which emphasized access to treatment in the context of HIV/AIDS as a human rights. And the 54th World Health Assembly meeting where two resolutions - Scaling Up the Response to HIV/AIDS and WHO Medicines Strategy ${ }^{57}$ - were adopted. The issues of high cost of drugs in poor countries and impact of international trade on public health were addressed in these resolutions. Many of these orga-

51. 'Common Working Paper of the EC, Hungary, Japan, Korea, Switzland and Turkey to the Seattle Ministerial Declaration', 29 November 1999, p. 3.

52. 't Hoen, supra n. 46, at p. 35.

53. W.J. Clinton, 'Remarks at a World Trade Organization Luncheon in Seattle', 35 Weekly Compilation of Presidential Documents 2494, 2427, 1 December 1999.

54. Executive Order No. 13,155, 65 Fed. Reg. 30,521 (2000).

55. UN Declaration of Commitment on HIV/AIDS, 25-27 June 2001, UN GAOR, 26th Special Session, Res. 33/2001.

56. African Summit on HIV/AIDS, Tuberculosis and other Related Infectious Diseases, AbujaNigeria, 24-27 April 2001, OAU/SPS/ABUJA/3.

57. The 54th World Assembly Meeting of May 2001, Res. 54.10 and 54.11. 
nizations were unanimous in the view that a strong intellectual property regime could be a barrier to access to life-saving medications in poor countries of the world.

\subsection{The Doha Declaration}

The Fourth Ministerial Conference of the WTO held in Doha in $2001^{58}$ is today regarded as a milestone in the debate on the impact of TRIPS on access to medicines in world's poorest countries. Prior to this meeting, a statement by the African Group on the need to confront the problem posed by access to medicines in the continent had been made handy in preparation for the Declaration. At the TRIPS Council meeting in June of 2001 the issue of TRIPS and public health for the first time received the attention of members. Here, Zimbabwe, representing the African Group, proposed issuing a separate declaration on the issue of access to medicines. This statement taking into cognizance the grave impact of HIV/AIDS pandemic in Africa reads that 'we propose that Members issue a special declaration on TRIPS and Access to medicines at the Ministerial Conference in Qatar, affirming that nothing in TRIPS Agreement should prevent members from taking measures to protect public health' ${ }^{59}$

In a follow up meeting of the Council in September of 2001 a whole day was devoted to a discussion on access to medicines. The African Group with another nineteen countries presented a joint proposal which would ensure that TRIPS will not hinder WTO members from formulating favourable public health policies. This statement also sought further clarifications on the use of flexibilities contained in the TRIPS. Interestingly a counter proposal was made by developed countries led by the US, Japan, Switzerland, Australia and Canada. The proposal emphasized the need to protect intellectual property for the sake of research and development claiming that intellectual property contributes to public health objectives globally. ${ }^{60}$ Undoubtedly, the purpose of this proposal by developed countries is to limit the use by developing countries of the flexibilities contained in the TRIPS Agreement.

After so much debate, diplomatic maneuvering and compromises, some remarkable conclusions were reached at the Doha conference. Perhaps one of the most significant of this seven-paragraph Declaration was the paragraph 4 of the Declaration which states:

58. WTO, Doha Ministerial Declaration on the TRIPS Agreement and Public Health, WTO Doc. No. WT/MIN(01)/DEC/2 (2001).

59. WTO Council for TRIPS, Special Discussion on Intellectual Property and Access to Medicines, WTO Doc. No. IP/C/M/31 (10 July 2001), p. 4.

60. 't Hoen, supra n. 46, at p. 37. 
'We agree that the TRIPS Agreement does not and should not prevent Members from taking measures to protect public health. Accordingly, while reiterating our commitments to the TRIPS Agreement, we affirm that the Agreement can and should be interpreted and implemented in a manner supportive of WTO Members' rights to protect public health and in particular to promote access to medicines for all.' ${ }^{61}$

This finally put an end to any doubt or controversy surrounding the use of the flexibility provisions contained in the TRIPS Agreement to advance the interests of public health.

In the opening paragraphs of the Declaration, members recognised the seriousness of public health issues confronting many developing countries and least developed countries, particularly those resulting from HIV/AIDS, tuberculosis and malaria. They thus stressed the need for the TRIPS Agreement to be a part of the solution in addressing these public health challenges. ${ }^{62}$

The Declaration further reassures that the safeguards contained in the TRIPS should be used to overcome any barrier intellectual property may pose to access to medicines. It confirmed, in unequivocal language, that the use of exceptions such as compulsory licensing is not limited to emergency or urgent situation only but rather it is left to members to determine when it is deemed fit to invoke. ${ }^{63}$ On the issue of parallel imports, the Declaration resolves that ' $[\mathrm{t}] \mathrm{he}$ effects of the provision in the TRIPS Agreement that are relevant to the use of exhaustion of intellectual property rights is to leave each member free to establish its own regime for such exhaustion without challenge'. ${ }^{64}$

Another important decision reached at the Declaration was the extension granted to least developed countries to implement the provisions of TRIPS. The earlier transition grace of 2006 was extended at Doha to 2016. This appears to be a relief for the least developed countries many of which are in Africa. ${ }^{65}$

Also, the Declaration reminded developed countries of their unfulfilled obligations under Article 66(2) of the TRIPS to provide incentives for their enterprises and institutions to promote technology transfer to least developed countries. ${ }^{66}$ The Declaration, however, was unable to find a solution to the troublesome Article 31(f) of TRIPS, which has been described as a stumbling block

61. Doha Declaration, supra n. 58, para. 4.

62. Ibid., paras. 1 and 2.

63. Ibid., para. 5 .

64. Ibid., para. 5(d).

65. This has further been shortened to 1 July 2013 or until they cease to be least developed countries whichever, date is earlier by the Council for TRIPS Decision of 5 November 2005 with the exclusion of patent on pharmaceutical products which still remains 1 January 2016. A decision which did not augur well with most of the least developed countries.

66. Many of these countries are from Africa. They include Angola, Benin, Burkina Faso, Burundi, Cape Verde, Central African Republic, Chad, Comoros, Democratic Republic of Congo, Djibouti, Equatorial Guinea, Eritrea, Ethiopia, Gambia, Guinea, Lesotho, Liberia, Malawi, Mauritania, Mozambique, Niger, Rwanda, Sierra Leone, Togo, Uganda, Tanzania, and Zambia. 
to the use of compulsory licensing by developing countries. Responding to this problem the Declaration resolves:

\begin{abstract}
'We recognize that WTO members with insufficient or no manufacturing capacities in the pharmaceutical sector could face difficulties in making effective use of compulsory licensing under the TRIPS Agreement. We instruct the Council for TRIPS to find an expeditious solution to this problem and to report to the General Council before the end of 2002.' ${ }^{67}$
\end{abstract}

In August of 2003 the Council for TRIPS reacted to this through a decision permitting member states with insufficient pharmaceutical manufacturing capacities to make effective use of compulsory licensing under the TRIPS. ${ }^{68}$ The Council mandated members to work towards a permanent solution to the problem which would involve an amendment of Article 31(f) of TRIPS. The contents and implications of this decision are considered in detail in subsequent sections of this article.

While the Declaration has been hailed as a ground breaking development in ensuring access to medicines for people in developing countries, its legal significance remains debatable. For instance, Skyes has observed that within the WTO system ministerial declarations are not 'legally binding' but may serve as persuasive authority in interpreting the TRIPS Agreement. ${ }^{69}$ Another commentator has suggested that the Declaration goes beyond merely clarifying provisions of TRIPS, but may also be relied on by a member state to challenge the legislation of another state for being TRIPS-non-compliant. ${ }^{70}$ Abbott has observed that the decision at Doha would 'appear to constitute an agreement on the method of application of the agreement within the meaning of Article 31(3)(a) of the Vienna Convention on the Law of Treaties (VCLT), and to be the substantive equivalent of an interpretation of the TRIPS Agreement'. ${ }^{1}$ While the legal effects of the Doha Declaration may not be certain, there is no doubt that the Declaration constitutes a consensus statement of the member states of WTO. This Declaration, if faithfully implemented, will no doubt promote access to life-saving medicines for Africans. But whether or not member states of WTO are committed to this Declaration form the basis of the discussion in the subsequent sections of this article.

67. Doha Declaration, supra n. 58, para. 6.

68. Implementation of Paragraph 6 of the Doha Declaration on the TRIPS Agreement and Public Health, Decision of the General Council of 30 August 2003, WTO Doc. IP/C/W/405.

69. A.O. Sykes, 'TRIPS, Pharmaceuticals, Developing Countries and the Doha "Solution", 3 Chicago JIL (2002) pp. 47-68.

70. 't Hoen, supra n. 46, at p. 42.

71. F.M. Abbott, WTO TRIPS Agreement and its Implications for Access to Medicines in Developing Countries, a report prepared for Intellectual Property Rights Commission (Washington DC, Intellectual Property Rights Commission 2002) p. 10. 
4.

Today it is no longer in doubt that the Doha Declaration constitutes a consensus statement of member states of WTO in protecting public health under the TRIPS Agreement. The fact that at Doha it was reiterated that member states have the right to invoke the exceptions provided under the TRIPS, particularly with regard to compulsory licensing, seems to vindicate attempts by developing countries like Brazil and South Africa to invoke these exceptions prior to Doha. The use of compulsory licensing has remained particularly very controversial even in the post Doha era. It has been widely agreed that many developing countries, especially those in Africa, lack the capacity to manufacture generics should they decide to invoke compulsory licensing in line with the TRIPS Agreement.

One of the unresolved issues in this regard by the Doha Declaration is what will become the fate of such nations? Will they be able to rely on imports from other countries? These questions have become very pertinent when one considers the fact that since January 2005 many developing countries have adapted their patent laws to be TRIPS-compliant, thus, making access to cheaper drugs more difficult. These issues including the origin and the grounds for the use of compulsory licensing and some development on its use are examined in this section of the article.

\subsection{Origin of compulsory licensing}

Compulsory licensing promotes competition and assures affordability of drugs while at the same time it enables patent holder to be compensated for the use of its invention. In most parts of the world, countries (developed and developing) have included provisions on compulsory licensing into their laws. ${ }^{72}$ Its use dates back to 1623 when the UK Statutes of Monopolies permitted the taking of a patent for lack of working. ${ }^{73}$ Similarly, under the French law forfeiture of patent for nonuse is permitted. ${ }^{74}$ The UK Patent Act of 1883 in its Section 23 allowed the use of compulsory licensing for cases in which the patent was not being worked in the UK, the reasonable requirements of the public were not satisfied, or any person was prevented from working or using an invention.

Under the Paris Convention of 1883 the use of compulsory licensing was provided for in Article 5(A).2 of the Convention. ${ }^{75}$ More recently, countries

72. C. Corea, Integrating Public Health Concerns into Patent Legislation in Developing Countries (Buenos Aires, South Center 2000) p. 7.

73. C. Correa, 'Intellectual Property Rights and the Use of Compulsory Licenses: Options for Developing Countries', Working Papers No. 5 (Geneva, South Centre 1999).

74. Ibid.

75. Art. 5(A).2 provides: 'Each country of the Union shall have the right to take legislative measures providing for the grant of compulsory licences to prevent abuses which might result 
like the US, under its antitrust law and other legislation, have included provisions on compulsory licensing. ${ }^{76}$ Countries such as Canada and Brazil have also provided for the use of compulsory licensing for the sake of medicines and public health. ${ }^{77}$

\subsubsection{Grounds for use of compulsory licensing}

Compulsory licensing is usually granted for lack of or insufficiency of working of an invention, to remedy anti-competitive practices, for cases of emergency, governmental or 'crown' use, and for other public interest grounds. ${ }^{78}$ Under Article 31 of the TRIPS Agreement compulsory licensing is allowed under different circumstances, including public emergency, high prices and as a measure to remedy anti-competitive practices. It has been argued that this provision is by no mean exhaustive as members may rely on other grounds to invoke use of compulsory licensing. ${ }^{79}$ In other words, the categories of circumstances justifying use of compulsory licensing are illustrative but not exhaustive. Many governments in developing countries have erroneously believed that compulsory licensing can only be used during a period of emergency. ${ }^{80}$ But this does not appear to be a correct interpretation of the TRIPS Agreement, as Article 31 never restricts the use of this exception to emergency situation alone but gives member states latitude to decide reasons for its use provided it is done in accordance with the provision of the TRIPS Agreement. It is recalled that during the ministerial meeting of WTO members in Doha an attempt to clarify this provision of TRIPS suggests that each member has the right to determine what constitutes a national emergency or other circumstances of extreme urgency. And that public health crisis, including those relating to HIV/AIDS, tuberculosis, malaria and other epidemics, can constitute such circumstances. ${ }^{81}$

It must be borne in mind that a member state that intends to make the use of compulsory licensing must fulfill conditions stated in Article 31. These include granting of the licenses on a case-by-case basis, proof of unsuccessful earlier request for voluntary license, non-exclusivity of the license and, importantly, requirement for compensation. Furthermore, Article 31(g) of TRIPS imposes a heavy burden on the compulsory licensing system. This provision seems to suggest the possibility that a compulsory license may be terminated as soon as

from the exercise of the exclusive rights conferred by the patent, for example failure to work.'

76. US Clean Air Act 1988 (42 USC Sec. 7608) and Atomic Energy Act 1988 (42 USC Sec. 2183).

77. Corea, supra n. 72, at p. 94.

78. Ibid., at p. 95.

79. R. Elliott, TRIPS and Rights: International Human Rights Law, Access to Medicines, and the Interpretation of WTO Agreement on Trade Related Aspects of Intellectual Property Rights (Toronto, Canadian HIV/AIDS Legal Network and AIDS Law Project 2001) p. 50.

80. Ibid.

81. Doha Declaration, supra n. 58, para. 4. 
the circumstances which led to its granting no longer exist. Corea has observed that a literal interpretation of this provision may 'discourage applications for compulsory licenses, since the licensee may be exposed to the revocation of his/ her right at any time' 82

In order for a country to be able to invoke compulsory licensing as a public policy instrument to promote access to medications, the following must be established:

a. It must be shown that a party granting the license within the country has the capability to exploit it either through manufacturing subject invention or importing it. This obviously requires financial ability or technical capability;

b. If local manufacturing of the subject of invention is to be undertaken, there must be evidence of adequate purchasing power among the local population to justify the investment by the party exploiting the license (or opportunities must be available). Where the population is small or poor, as in most African countries, there may not be a guarantee of returns for investment;

c. Where the government is the party exploiting the compulsory license for government use - or as purchasing agent on behalf of the population acquiring the invented subject, there must be evidence of financial resources or technical capability;

d. There must be evidence of an existing sound legal and political structure to permit the granting and monitoring of the license. ${ }^{83}$

It would appear that going by these pre-conditions for exploiting compulsory licensing; only developed countries and few developing countries would be able to successfully make use of this exception. Many African countries, possibly with the exception of South Africa and Egypt, lack the financial wherewithal and the technical expertise to meet these pre-conditions. Notwithstanding, the issuance of compulsory licensing, especially in case of import, remains a viable tool in advancing access to medicines and the right to health in Africa. This is because it promotes competition and breaks the monopoly enjoyed by a patent holder on drugs, thus facilitating access to cheap drugs. In fact developed countries like America and Canada despite their level of development and wealth, were forced to threaten the use of compulsory license over Bayer's ciprofloxacin, a drug useful for the treatment of anthrax, at the wake of bioterrorism attack. ${ }^{84}$ More recently a similar step was taken in the wake of the bird-flu attack. This seems to underline the importance of compulsory licensing in breaking monopoly of a patent holder on medicine.

82. Corea, supra n. 73 , at p. 8 .

83. Abbott, supra n. 71, at p. 14.

84. D. Alexander, "Duplicated" drugs life-line for millions in Africa: US anthrax scare renews debate on generic drugs law', The Monitor, 1 November 2001, p. 15. 
As noted earlier pharmaceutical companies and developed countries led by the US have shown irascible attitudes to the use of compulsory licensing. They have argued that it not only erodes patent right, but may encourage manufacturing of sub-standard drugs. This indeed is a weak and face saving argument that lacks merit and is insensitive to millions of lives in need of essential medicines in Africa. Experience has shown that generic drugs manufactured in Indian and Brazil have been found to be of good quality, some even are listed under the WHO Essential medicines list. $^{85}$

\subsubsection{Limitation under Article 31(f) TRIPS}

One important limitation to the use of compulsory licensing is found in Article 31(f) of TRIPS. This provides that 'any such use shall be authorised predominantly for the supply of the domestic market of the Member authorising such use'. The import of this phrase in paragraph (f) of Article 31 is unclear. If taken narrowly it would seem to suggest that compulsory licensing can only be used for local consumption and not for export. The likely implication of this for developing countries and least developed countries, particularly those in Africa, will be that compulsory licensing may not be useful for many of them that lack technological capacity to reverse engineer and manufacture drugs locally. In such countries access to HIV/AIDS medications may remain an unattainable dream.

Abbott has pointed out that this provision constitutes an obstacle to realising access to medicines for people in poor population as in Africa in two ways. First, by limiting availability of export drugs made under compulsory licensing, it invariably restricts countries that are unable to support manufacturing under compulsory licensing (or where patent protection is not in force) in the availability of supply of generic import drugs. Second, requiring compulsory licensees to restrict a predominant part of their production to domestic market, limits flexibility of countries to authorise the export of compulsory-licensed drugs and thus to exploit economy of scale. ${ }^{86}$

The practical implication of Article 31(f) will be that, if a country like South Africa that has the capacity to manufacture generic drugs, has invoked the use of compulsory licensing, it still cannot supply neighbouring countries such as Lesotho or Swaziland that lack capacity to manufacture but are in dire need of drugs for HIV/AIDS. In the same vein, Lesotho and Swaziland would be unable to declare compulsory licensing to import life-saving medications from South Africa. Thus, demand and supply for life-saving drugs are adversely affected.

85. See IAVI Report, 'Indian ARVs are returned to WHO's arsenal of approved medicines', 3 Bulletin on Aids Vaccines (August 2005), available at <www.iavireport.org/vax/english/ Vax_2005\%20_aug.pdf $>$ (accessed on 8 June 2007).

86. Abbott, supra n. 71, at p. 17. 
This obviously produces an anomalous situation as it prevents access to lifesaving medicines for those in dire need.

But could this be the aim of the provision? Baker has suggested that a generous interpretation be given to this provision so as to justify an exporting country to export a major portion of its production, provided such exports were necessary to have a large production runs so as to efficiently supply the domestic market. ${ }^{87}$ This interpretation would seem to tally with the central principles of TRIPS under Article 8. In Lowenfeld's view, this provision can be interpreted to mean that goods under compulsory licensing should not be for 'export in competition with the patent holder' ${ }^{88}$ Certainly, Article 31(f) never prohibits the issuance of compulsory licensing for export purpose; it merely places a restriction on such export.

The truth, however, remains that many developing countries, particularly African countries, lack even the capacity to produce formulations and only a few of these countries invest in research and development for new drugs or even conduct research in the pharmaceutical sector. ${ }^{89}$ The only hope for such countries will be to rely on the use of compulsory licensing for import of generic drugs. Generic drugs can improve health care and reduce the monopoly or oligopoly powers of patent holder, but this possibility is remote and subject to controversy. ${ }^{90}$

During the ministerial council meeting of WTO members in Doha this issue came up. It was noted that WTO members with insufficient or no manufacturing capacities in the pharmaceutical sector could face difficulties in making effective use of compulsory licensing under the TRIPS Agreement. Therefore, a recommendation was made to the Council for TRIPS 'to find an expeditious solution to this problem'. ${ }^{91}$ This issue is particularly more germane in the light of the January 2005 deadline for developing countries like India to be TRIPScompliant. It is to be noted that India supplies about half the generic drugs in Africa. ${ }^{92}$ The likely implication of this change remains uncertain.

87. B.K. Baker, 'Arthritic Flexibilities for Accessing Medicines: Analysis of WTO Action Regarding Paragraph 6 of Doha Declaration on the TRIPS Agreement and Public Health', 14 Indiana International and Comparative Law Review (2004) p. 613 at p. 665.

88. A.S. Lowenfeld, International Economic Law (Oxford, Oxford University Press 2002) p. 108.

89. C. Corea, Implications of Doha Declaration on the TRIPS Agreement and Public Health (Geneva, WHO 2002) p. 22.

90. K.R. Sirinivas, 'Interpreting Paragraph 6 Deal on Patents and Access to Treatment', Economic and Political Weekly, 20 September 2003.

91. Doha Declaration, supra n. 58, para. 6.

92. Guardian Unlimited (Special Reports), 'Cheap AIDS Drugs under Threat', available at $<$ www.guardian.co.uk/aids/story/0,7369,1443872,00.html> (accessed on 20 September 2005). 


\subsection{The August 2003 Decision of the Council for TRIPS and its implications}

In what appears to be a temporary solution to the paragraph 6 problem of Doha Declaration, the Council for TRIPS responded in 2003 through a decision permitting member states with insufficient pharmaceutical manufacturing capacities to make effective use of compulsory licensing under the TRIPS. ${ }^{93}$ The Decision, which was arrived at just a few days to the WTO meeting in Cancun, is to the effect that countries with manufacturing capacity, in the meantime, can export essential medicines to countries with no or insufficient manufacturing capacity. This has been described as a temporary waiver to the paragraph 6 problem of Doha Declaration. The Decision in its opening paragraph purports to limit diseases for which compulsory licensing may be issued to diseases mentioned in paragraph 1 of Doha Declaration that is, HIV/AIDS, tuberculosis and malaria. The rationale for this is unclear, however; Baker has argued that a broad and generous interpretation should be given to paragraph 1 of Doha as to cover other important diseases. ${ }^{94}$

The waiver can be used to the extent necessary for the purposes of producing a pharmaceutical product for export subject to certain conditions. The importing member must be either a least developed country, or a developing country having established insufficient capacity in the pharmaceutical sector, and having granted a compulsory license in accordance with Article 31 of the TRIPS Agreement. ${ }^{95}$ An additional hurdle was further created by the Chairperson's Statement which accompanied the Decision. ${ }^{96}$ Thus, a developing country wishing to issue compulsory licensing for the purpose of import must notify the Council for TRIPS which will in turn review the notification before giving the go ahead. This will either cause some delay in case of urgent need of drugs to address an epidemic or may even discourage developing countries from issuing compulsory licensing for fear of litigation which may arise from such notification.

Under the Decision an exporting member country is broadly defined to include any WTO member state. However, a restriction is placed on the quantity of medicines that can be produced for export under a compulsory license. ${ }^{97}$ The Chairperson's Statement further states that a country issuing compulsory licensing for export will do so on a non-commercial basis. This could be a restriction on the right of generic exports and may even discourage issuing compulsory licensing. One may ask: what is the basis for such restriction? Since

93. Implementation of para. 6, supra n. 68.

94. Baker, supra n. 87 , at p. 635.

95. Implementation of para. 6, supra n. 68, para. 2.

96. The General Council Chairperson's Statement, 30 August 2003, available at <www.wto. org/english/news_e/news03_e/trips_stat_28aug03_e.htm > (accessed on 20 August 2007).

97. Implementation of para. 6, supra n. 68, para. 2(b). 
the whole essence of producing and exporting generic drugs will be to make a degree of profit at least to sustain further production.

Similarly, an exporting member, under this Decision, shall notify the Council for TRIPS of the grant of the license with some vital information. Such information will include, name and address of the licensee, the product(s) for which the license has been granted, the quantity or quantities for which it has been granted, the country or countries to which the product(s) is (are) to be supplied and the duration of the license. In addition the address of the website of which the licensee posts its required notifications shall be furnished. ${ }^{98}$ In order to prevent diversion of goods meant for developing countries to developed countries, the Decision required special branding and packaging labels for drugs produced for export under the Decision.

The Decision also permits regional procurement of drugs for compulsory license issued under it so as to harness economies of scale and facilitate local production of drugs. ${ }^{99}$ This may be advantageous to African countries that are already members of regional economic groups as they will be able to pull resources together to purchase needed drugs and expand markets for local production of generic drugs.

Overall this Decision by the Council for TRIPS seems to create more hurdles than solution to the paragraph 6 problem of Doha. Sirinivas summarizes the challenges created by this decision in this way:

'Under this deal however serious the health situation be a developing nation which lacks the capacity to manufacture the needed drugs will have to request another government to invoke compulsory licensing or suspend the rights of the patent holder and provide licence to local firm or firms to produce and export the needed drugs. The deal adds many layers of procedures to the whole process. They have to notify the TRIPS Council, about the intention to use this system and the country that has issued the compulsory licence has to meet many conditions and all these measures not only will delay the manufacture and supply but also increase the cost of the drugs.' 100

It has further been observed that this Decision by the TRIPS Council and the subsequent statement of its chairman "contain several conditions and measures which exporting and importing countries have to comply with, raising concerns amongst analysts that they are too cumbersome and thus rendering the "temporary solution" difficult to operate'. ${ }^{101}$ One may reasonably conclude that this Decision is not faithful to the spirit of Doha nor is it consistent with promoting the right to

98. Ibid., para. 2(c).

99. Ibid., para. 6.

100. Sirinivas, supra n. 90.

101. S. Shashikant, 'Heated Discussions as TRIPS and Health Para 6 Deadline Is Missed', Third World Network, 5 April 2005, available at <www.twnside.org.sg/title2/twninfo197.htm> (accessed on 1 July 2007). 
health. In Love's view, this Decision means nothing but an endorsement of a new model of explicit protectionism. He states further:

'The US, Europe, Canada, Australia, Japan and other developed economies will be allowed to bar imports from developing country generic suppliers - under completely irrational protectionist measures that are defended by the WTO Secretariat and its most powerful members as a humanitarian gesture.' 102

According to Corea this so-called Decision is merely symbolic in nature and falls short of what can be regarded as 'an expeditious solution' ${ }^{103} \mathrm{He}$ argues further that the series of conditions that need to be satisfied to make use of this Decision will ultimately deprive poor countries of the world needed access to life-saving medicines.

Many activists and NGOs working on access to essential medicines for poor population have described the Council for TRIPS Decision as a 'gift bound in red tape'. ${ }^{104}$ Rather than solve the paragraph 6 problem, it has merely compounded it. To the extent that this Decision blocks, rather than facilitates access to medications for people in developing countries and in particular Africa, it is a threat to the enjoyment of the highest attainable standard of physical and mental health.

The Council in paragraph 11 of its Decision mandated members to work towards a permanent solution to the problem which will involve an amendment of Article 31(f). Unfortunately, it took a while before this solution could be found. Several meetings by the Council to find a solution to the problem had initially ended in deadlocks. Developed countries led by the US and members of the EC stood in the way of permanent solution to the problem claiming that it would render patent rights meaningless.

Developing countries on the other hand, particularly the African Group, insisted on a permanent solution to paragraph 6 problem of Doha as the only way out to save lives of million of people dying of various diseases in the region. However, just a few days to the WTO meeting in Hong Kong, precisely on 6 December 2005 the Council for TRIPS, acting on behalf of the Ministerial Council, finally adopted an amendment to the TRIPS as a permanent solution to paragraph 6 problem of Doha. This becomes the first amendment ever to a core WTO Agreement since its inception in 1995.

102. J. Love, 'CPTech Statement on WTO Deal on Exports of Medicines', 30 August 2003, available at <www.cptech.org/ip/wto/p6/cptech08302003.html> (accessed on 28 June 2007).

103. C. Corea, 'Recent International Developments in the Area of Intellectual Property Rights', ICSTD-UNCTAD Dialogue, 2nd Bellagio Series on Development and Intellectual Property, 18-21 September 2003, available at <www.iprsonline.org/unctadictsd/bellagio/docs/Correa Bellagio2.pdf> (accessed on 10 March 2008).

104. 'Joint NGO Statement On TRIPS and Public Health: WTO Deal On Medicines A "GIFT" Bound in Red Tape', 30 September 2003, available at <www.cptech.org/ip/wto/p6/ngos09102003. html $>$ (accessed on 26 June 2007). 


\subsection{The 6 December 2005 amendment of the TRIPS Agreement}

The so-called amendment to the TRIPS adopted by the Council for TRIPS on 6 December 2005 was not different in elements, substantially from the 30 August 2003 Decision of the Council, save for some slight changes in structures and few changes that are now added to the amendment. However, before examining these changes it is apposite to consider the relationship between the August 2003 Decision of the Council and its amendment of December 2005. ${ }^{105}$ Essentially, one major point to note in this respect, as provided in paragraph 11 of the amendment, is the fact that the Decision remains operative in a WTO member state until the date the amendment takes effect in that member state. In other words, the amendment has in no way abolished the Decision. Since the effective date of the amendment is not clearly ascertained, the implication of this is that the Decision may still for sometime be binding on member states.

Also, paragraph 11 similarly states that the amendment will be based, where necessary on the Decision. Thus, suggesting that, although the amendment need not contain same terms as the Decision, essential elements of the Decision will become part of the amendment. Considering the criticism levied against the Decision by many developing countries this provision attracted some opposition from the African Group during the negotiation of the amendment. This Group had proposed a substantial modification of the provision of paragraph 11 contending that certain elements of the Decision were inappropriate for the amendment. ${ }^{106}$ However, this argument did not seem to see the light of the day as eventually the amendment contains the same elements as the Decision.

The amendment to TRIPS can be classified into three main parts. Firstly, there is Article 31 bis which contains about five paragraphs, that tally to a great extent with the main text of paragraph 2, 3, sub-paragraph 6(1), paragraph 10, and 9 of the Decision respectively.

Secondly, the other part of the amendment is the Annex to the TRIPS Agreement which contains 7 paragraphs corresponding in substance to paragraph 1 , sub-paragraphs 2(a), 2(b) and 2(c), paragraphs 4 and 5, sub-paragraph 6(ii) and paragraphs 7 and 8 of the Decision respectively.

Finally, there is the Appendix to the Annex to the TRIPS Agreement which corresponds substantially to the Annex to the Decision.

Although one can argue that the substantive contents of the amendment in relation to rights and obligations of WTO members remain essentially the same

105. WTO General Council, Amendment of the TRIPS Agreement of 6 December 2005, WT/L/641.

106. See 'The 6 December 2005 TRIPS Amendment and Public Health at the WTO', Intellectual Property Quarterly Update, Fourth Quarterly 2005, available at <www.ciel.org/Publications/ IP_Update_4Q05.pdf> (accessed on 21 November 2007). The African Group in February of 2005 had come up with what appeared to be a very good proposal as a solution to the para. 6 of Doha but this proposal was stiffly opposed by the US and the EC countries. 
as that of the Decision, however, there exist some major differences between the two. For instance, the preamble to the Decision is not included in the amendment even though some of the text is included in the General Council's Decision adopting the amendment.

Also, paragraph 6 of the Decision is now broken into two parts. The first part - paragraph 6(i) of the Decision - contained in paragraph 3 of Article 31 bis and the other - paragraph 6(ii) - contained in paragraph 5 of the Annex to the TRIPS Agreement. Paragraph 6(i) essentially lays down the rules for re-export. This provision came about as a form of legal solution to the problems developing countries, such as in sub-Sahara Africa with small markets, may encounter in effectively making use of compulsory licensing.

The provisions of paragraph 3 of Article 31 bis state that in order to create economies of scale and facilitate local production of pharmaceutical products, the requirement under the Annex stating that only the quantity necessary to meet the needs of the importing member state would be manufactured under the license would not apply if the products were exported or re-exported to other developing countries or least developed countries within a regional trade agreement, where half of the members are least developed countries. Paragraph 5 of the Annex deals with the issue regarding systems of regional patents.

Similarly, paragraph 8 of the Decision has been modified to exclude the last sentence which made reference to annual review being deemed to fulfilling the requirements of Article IX(4) of the WTO Agreement. This modification, as pointed out by the African Group, has become necessary in view of the fact that the review under Article IX(4) is only applicable to the waiver and since this is an amendment the provision has become otiose and does not apply. ${ }^{107}$

It was agreed that the entry into force of the amendment will have to be determined in accordance with the rules guiding amendments under the WTO Agreement. The proper provision for this is found in Article X(3) of the WTO Agreement which is to the effect that any amendment to the WTO Agreement shall take effect upon acceptance by two third of members that have accepted it and thereafter for each other member upon acceptance by it. ${ }^{108}$ The provision equally gives the Ministerial Council the discretion, by a three-fourths majority, to give a member that is yet to accept an amendment to the WTO Agreement

107. See the legal arguments of the African Group, WTO Doc. IP/C/W/440, ibid. The African Group argued that certain provisions of the Decision, which have outlived their usefulness, since their purposes have already been served, will become redundant in the context of an amendment. These were referred to as self-eliminating. An example of this is para. 11 of the amendment which defines relationship between the amendment and the Decision and establishes timeliness for the work on the amendment.

108. Presently 28 countries (inclusive of the 15 members of the EC) out of 150 members of the WTO have accepted this amendment so far as at 1 January 2008. They include the US, India, Switzerland, El Salvador, Norway, Philippines, Australia, Japan, Israel, Singapore, China, Hong Kong, Republic of Korea and members of the EC. Information available at <www.wto.org/english/ tratop_e/trips_e/amendment_e.htm> (accessed on 1 February 2008). 
a certain period of time to do so or be advised to withdraw its membership of WTO.

The Protocol to the amendment provides that it shall be opened for acceptance to members until 1 December 2007, that is, about two years from the date of its adoption or such other day as decided by the Ministerial Council. What this means is that the exact date of entry into force of the amendment is not known but will be dependent upon acceptance (ratification) by two-third of WTO members. Moreover, it could be assumed that the exact date for entry into force is before or after 1 December 2007. It is to be noted that even if the amendment eventually enters into force it may likely create an anomalous situation - temporarily - where the amendment will apply to certain members and the Decision to other members since, as mentioned earlier the amendment has not come to abrogate the Decision instantly.

Since the amendment to the TRIPS is based on the Decision of the Council for TRIPS the same criticisms levied against the Decision, earlier mentioned in this article, apply to the amendment. Infact, MSF has noted that it is disappointing and almost unbelievable that the Council adopted an amendment based on the unworkable and cumbersome August 2003 Decision. ${ }^{109}$ Gathii similarly adds that in reality the practicability of the so-called amendment may prove illusory for poor countries due to the implausibility of the several conditions attached to it. ${ }^{110}$ In actual fact, since the Decision - which has now given birth to this amendment - was adopted in 2003 just one country has been able to successfully put it into use. ${ }^{111}$ As noted below an attempt made by MSF based on a new Canadian legislation - which was a response to the August 2003 Decision - failed due to the bureaucratic entanglements in the procedures.

While it is admitted that this amendment to the TRIPS Agreement strives to resolve the paragraph 6 problem of the Doha Declaration, it is doubtful whether it will achieve this aim. This is because the several hurdles that need to be overcome before a developing country can invoke the use of compulsory licensing, under it, are a betrayal of the spirit of Doha Declaration. It is like an albatross hanging on the necks of developing countries. It does not serve the interest of Africans, neither is it consistent with realising the right to health of vulnerable and marginalized people worst affected by life threatening diseases.

109. MSF, Neither Expeditious, Nor a Solution: The WTO August 2003 Decision is Unworkable (Geneva, MSF 2006) p. 6.

110. J. Gathii, 'How Necessity May Preclude State Responsibility for the Compulsory Licensing Under the TRIPS Agreement', 31 North Carolina Journal of International Law and Commercial Regulation (2006) p. 943 at p. 956.

111. Rwanda being a least developed country made a notification to the Council for TRIPS in accordance with para. 2(a) of the 30 August 2003 Decision to import triple combination Triavir from Canada. In same manner Canada has made a notification to the Council in October 2007 to export same drugs to Rwanda in line with para. 2(c) of the 2003 Decision. 


\subsection{The Zimbabwean experience}

Zimbabwe remains one of the countries with high prevalence rate of HIV/AIDS infection in sub-Sahara Africa. With a population of about 12 million people it is estimated that about 20 percent of Zimbabweans are living with HIV/AIDS. This translates to about one in four Zimbabweans. Life expectancy has dropped from 70 years before the HIV/AIDS pandemic to about 40 years. ${ }^{112}$ In May of 2002, the Zimbabwean government faced with about 2,000 weekly deaths caused by AIDS related complications and lack of access to life-saving medications for the people due to high prices of ARVs, declared HIV/AIDS a state of emergency in the country. At this period the price of first line therapy for treating HIV/AIDS, cost about 1,168 US dollars per person for a year compared to about 412 dollars of its generic version from India. ${ }^{113}$ Only very few Zimbabweans could afford this.

The government relying on Sections 34 and 35 of its Patent law ${ }^{114}$ declared as follows:

'In view of the rapid spread of HIV/AIDS among the population of Zimbabwe, the Minister hereby declares an emergency for a period of six months, with effect from the date of promulgation of this notice, for the purpose of enabling the State or a person authorised by the Minister under section 34 of the Act

(a) to make or use any patented drug, including any antiretroviral drug used in the treatment of persons suffering from HIV/AIDS or HIV/AIDS related conditions;

(b) to import any generic drug used in the treatment of persons suffering from HIV/ AIDS or HIV/AIDS-related conditions.' ${ }^{115}$

According to Section 35 of the Zimbabwean Patent Act, powers given to a state department or an authorised minister under Section 34 in relation to an invention, shall include the power to make, use, exercise and vend the invention for any purpose which appears to the Minister necessary or expedient. These powers can be exercised in the following situations

a. for the efficient prosecution of any war in which Zimbabwe may be engaged; or

b. for the maintenance of supplies and services essential to the life of the community; or

c. for securing a sufficiency of supplies and services essential to the well-being of the community; or

112. MSF, 'Zimbabwe government takes emergency action against HIV/AIDS Overriding patents will dramatically cut price of treatment for patients', available at <www.cptech.org/ip/ health/c/zimbabwe/msf05292002.html> (accessed on 24 June 2007).

113. Ibid.

114. Patent Act (Chapter 26:03) of 1971 which has been amended severally with the last amendment taking place in 1994.

115. See General Notice 240 of 27 May 2002, 'Declaration of Period of Emergency'. 
d. for promoting the productivity of industry, commerce or agriculture; or

e. for fostering and directing exports and reducing imports or imports of any classes, from all or any countries and for redressing the balance of trade; or

f. generally, for ensuring that the whole resources of the community are available for use, and are used, in a manner best calculated to serve the interests of the community; or

g. for assisting the relief of suffering and the restoration and distribution of essential supplies and services in any part of Zimbabwe or any foreign country that is in brave distress as the result of war.

At the time Zimbabwe was issuing compulsory licensing on patented drugs it lacked the necessary technical capacity to manufacture generic drugs locally. Thus, the only option opened to it then was to embark on import. It is worthy to note that at this time the paragraph 6 problem of Doha was yet to be resolved. The initiative and decisiveness of the Zimbabwean government to respond to the devastating effects of the HIV/AIDS pandemic in the country, through invocation of compulsory licensing is quite commendable. It provides a good precedent for other African countries to emulate. This seems to tally with the country's obligations to respect, protect and fulfill the right to health guaranteed under Article 12 of ICESCR and Article 16 of the African Charter both of which have been ratified by Zimbabwe. ${ }^{116}$ Indeed the African Commission in the Purohit case has held that states have an obligation to ensure that health care facilities and commodities including drugs are made available to their citizens. ${ }^{117}$ But what can not be understood is the reason behind the six months period for the license. Considering the magnitude of loss of lives caused by AIDS related illness in the country a longer period of time would have been appropriate pending the time situation improves.

It is pertinent to observe that about three years after Zimbabwe invoked the use of compulsory licensing the situation as regards access to HIV/AIDS medicines in that country has not improved. A report has it that at the end of 2006 of about 350,000 people in need of ARVs in the country only 52,000 were receiving them. ${ }^{118}$ Similarly in October of 2005 it was reported that prices of ARVs in the country had quadrupled in the previous three months. ${ }^{119}$ Moreover, there have been reported cases of severe shortages in health care workers and

116. See S. Sacco, 'A Comparative Study of the Implementation in Zimbabwe and South Africa of the International Law Rules that Allow Compulsory Licensing and Parallel Importation for HIV/AIDS Drugs', 5 African Human Rights Law Journal (2005) p. 105.

117. Purohit and Moore v. The Gambia, Communication 241/200, decided at the 33rd ordinary session of the African Commission (15-29 May 2003).

118. WHO, 'Towards Universal Access: Scaling up Priority HIV/AIDS Interventions in the Health Sector', April 2007, available at <www.who.int/hiv/mediacentre/univeral_access_ progress_report_en.pdf (accessed on 4 July 2007).

119. AVERT, 'HIV \& AIDS in Zimbabwe', available at <www.avert.org/aids-zimbabwe. htm $>$ (accessed on 3 July 2007). 
other administrative problems in sites where government treatment has been provided. Compounding the situation further, the harsh economic condition of the country - rising inflation and shortage of foreign currency - has translated to a critically low supply of ARVs in the country. Sustaining importation of generic drugs into the country is become increasingly difficult. This is an indication that the use of compulsory licensing - whether for import or to manufacture drugs locally - requires essentially both technological capability and political commitment on the part of a government.

This Zimbabwe example clearly exemplifies some of the problems the issuance of compulsory licensing may cause in Africa. It may be possible for a country to have a protective patent law which permits the use of compulsory licensing yet the country may be unable to effectively sustain the issuance of the license as seen from this Zimbabwean experience. The situation becomes more challenging where a country is faced with grave political and economic problems as Zimbabwe - this happens to be the lot of many African countries. In such situations, issuing compulsory licensing to import generic drugs may prove very challenging.

\subsection{Exploring alternatives for African countries}

A number of suggestions have been offered by commentators as the way out of the paragraph 6 problem of Doha. These suggestions have become particularly relevant in the light of the controversial amendment to the TRIPS Agreement by the Council.

For instance, a commentator has suggested the use of the non-justicability exception regarding exhaustion of rights under Article 6 as a way out since this exception is not subject to settlement dispute under the TRIPS. ${ }^{120}$ Others have suggested the use of Article 31(b) and (k) of TRIPS as necessary provisions to ensure access to affordable drugs to Africans. Furthermore, Gathii argues that African governments can invoke the principle of state necessity under international law to resort to the use of compulsory licensing without legal responsibility under the TRIPS Agreement. ${ }^{121}$ This article only considers the possible viability of the suggestion under Article $31(\mathrm{k})$.

\subsubsection{Article 31(k) TRIPS}

This provision is very important and may be used as an exception to the limitation under Article 31(f) and the paragraph 6 Decision of the Council for TRIPS. It provides as follows:

120. Commission for Intellectual Property Rights (CIPR), Integrating Intellectual Property Rights and Development Policy (London, CIPR 2002) p. 32.

121. Gathii, supra n. 110, at p. 957. 
'Members are not obliged to apply the conditions set forth in subparagraphs (b) and (f) where such use is permitted to remedy a practice determined after judicial or administrative process to be anti-competitive. The need to correct anti-competitive practices may be taken into account in determining the amount of remuneration in such cases. Competent authorities shall have the authority to refuse termination of authorization if and when the conditions which led to such authorization are likely to recur; ...'

It thus appears from this provision that a generic manufacturer operating under a compulsory licensing could do so on a large scale for export purpose especially when a non-special and a non-paragraph 6 compulsory license have been granted in the importing country. ${ }^{122}$

Under the TRIPS Agreement the definition of what may amount to 'anti competitive practice' is not provided. Thus, individual countries may provide appropriate definition to this phrase in their own laws. This will be in line with the provisions of Article 1 which requires member states to fashion an appropriate method of implementing the TRIPS Agreement and Article 8(2) which permits member states to prevent abuse of intellectual property rights by rights holders which unreasonably restrains trade. It has been argued that drug patents by their very nature constitute anti-competitive practices. This is because they allow the patent owners to exclude other manufacturers and vendors from exploiting the same product. ${ }^{123}$ The inevitable result of this will be high or excessive pricing of products.

In case of HIV/AIDS medications where demands for them are said to be inelastic, prohibitive costs of these drugs in many African countries can be argued to amount to an act of anti-competition. This argument is buttressed further if it can be established that reasonable access to medicines are being denied due to high prices which have no bearing to the production costs, and that the patent holder has unreasonably refused to license its patent to generic producers. Under this circumstance it may be justified for a country to invoke compulsory licensing as provided in Article 31(k).

A good example exists in the case of South Africa. Under the South African Competition Act it is provided that all people will benefit from an efficient and competitive development-oriented market that balances producer, consumer and worker interests. ${ }^{124}$ The Act further provides supports to a market 'in which consumers have access to, and can freely select, the quality and variety of goods and services they desire'. ${ }^{25}$ Section 1(2)(a) provides that in furtherance of the goal of the Act as stated in the preamble, the Act will be interpreted in a manner

122. Baker, supra n. 87, at p. 664.

123. Ibid.

124. Preamble to the Competition Act of South Africa No. 89 (1998).

125. Ibid. 
which gives effect to its purposes, which include the provision of 'competitive prices and product choices' ${ }^{126}$ and 'advancing social and economic welfare'. ${ }^{127}$

In 2003 the Treatment Action Campaign (TAC) lodged complaints against two big pharmaceutical companies - GlaxoSmithKline and Boerhringer of Ingelheim - for charging excessive prices for their patented anti-retroviral drugs. In its ruling of October 2003, the South African Competition Commission found the two pharmaceutical companies in violation of the competition law by charging excessive prices and unreasonably refusing to issue voluntary licenses to generic competitors. ${ }^{128}$ The Commission further held that these acts of the pharmaceutical companies had unreasonably restricted access to an essential facility preventing production of fixed-dose combination medicines. The Commission therefore authorised any person to exploit and market generic versions of patents held by the two companies. In addition, it asked the two companies to pay a penalty of about ten percent of annual turnover of their ARVs sales in South Africa. Based on this decision the two companies announced voluntary licensing agreement with the complainants.

To support the assertion that Article $31(\mathrm{k})$ is not subject to paragraph 6 Decision of the Council for TRIPS is the provision of paragraph 9 of the Decision itself. That paragraph provides thus:

'This Decision is without prejudice to the rights, obligations and flexibilities that Members have under the provisions of the TRIPS Agreement other than paragraph (f) and (h) of Article 31, including those reaffirmed by the Declaration, and to their interpretation. It is also without prejudice to the extent to which pharmaceutical products produced under a compulsory license can be exported under the present provisions of Article 31(f) of the TRIPS Agreement.'

In view of the disappointing decision reached by the Council for TRIPS on paragraph 6 of Doha and its subsequent amendment of the TRIPS Agreement, Article $31(\mathrm{k})$ offers a way out for African countries to ensure affordability of drugs to their citizens by importing cheaper generic drugs through the use of compulsory licensing. But of course African governments must ensure that a clearly stated provision on compulsory licensing is contained in their patent laws. Moreover, a properly drafted competition legislation must exist which should clearly state what will amount to anti-competitive practice and the penalty for such practice. This has become very important in that, African governments are under obligations under international law to take every measure to ensure affordable drugs for their citizens. As noted by the Committee on

126. Ibid., Section 2(b).

127. Ibid., Section 2(c).

128. See 'Competition Commission finds GSK and BI in Contravention of the Competition Act', available at <www.tac.org.za/newsletter/2003/ns16_10_2003.htm> (accessed on 10 July 2007). 
ICESCR in its General Comment 14, states have the duty to fulfill the right to health through legislative, administrative, budgetary and judicial steps. ${ }^{129}$ This duty encompasses a facilitative role on the part of the state - ensuring provision of cheaper life-saving drugs for citizens by third parties through appropriate legislation and policy.

\section{SOME DEVELOPMENTS IN THE USE OF COMPULSORY LICENSING}

There have been some developments with respect to the use of compulsory licensing in recent times. In October 2002, the European Parliament adopted an amendment to the European Medicines Directive which states that 'manufacturing shall be allowed if the medicinal product is intended for export to a third country that has issued a compulsory license for that product, or where a patent is not in force and if there is a request to that effect of the competent public health authorities of that third country'. ${ }^{130}$ Haochen has noted that this creates a good policy framework to balance the objectives of paragraph 4 of the Doha Declaration, while protecting the interests of patent owners. ${ }^{131}$ In response to the August 2003 Decision, a 2006 Regulation of the European Parliament has permitted use of compulsory licensing in EU members for export to least developed countries or other countries with incapacity to manufacture generic drugs and that has notified the Council for TRIPS. ${ }^{132}$ It is worthy to mention that Article 6 of the Regulation urges EU members not to adopt any law or policies that will render cumbersome or difficult the application of the use of compulsory licensing within their territories.

Another important development relates to a law passed by the Canadian government recently which aims at facilitating export of lower cost generic drugs to developing countries that lack the capacity to manufacture pharmaceutical products. ${ }^{133}$ This law allows the issuance of compulsory licences for generic pharmaceutical manufacturers to make generic versions of patented pharmaceuticals for export to countries that lack their own manufacturing capacity. The passage of Jean Chrétien Pledge to Africa, makes Canada the first country to adopt a law which permits the export of generic medicines manu-

129. General Comment 14, supra n. 13, para. 38.

130. Council Directive 2001/83/EC. Amendment 196 to the European Medicines Directive, adopted 23 October 2002.

131. S. Haochen, 'A Wider Access to Patented Drugs under the TRIPS Agreement', 21 Boston Univ. ILJ (2003) p. 101.

132. Regulation (EC) No. 816/2006 of the European Parliament and of the Council of 17 May 2006 on compulsory licensing of patents relating to the manufacture of pharmaceutical products for export to countries with public health problems.

133. The Jean Chrétien Pledge to Africa Act, Bill C-9 (2004) amends the Patent Act and the Food and Drugs Act. 
factured under compulsory license from a developed country to developing countries in the post August 2003 Decision. Under this law, the amount to be paid as royalty for use of a patent will depend on the ranking of the importing country on the UN Development Programme's Human Development Index (HDI). This may be in the interest of African countries as they are likely to be among the importing countries targeted under the law. This law has been hailed as a positive development in promoting access to medicines for poor countries of Africa. The law has also received the blessing of the North American Free Trade Agreement (NAFTA), ${ }^{134}$ a treaty which requires strict protection for patent holders in North America.

The law, however, contains some limitations such as restrictions on non-WTO members to qualify as importing countries for the purpose of benefiting from exports under the law. It has also been criticised for allowing patent holders to apply for a court order terminating a compulsory licensing or ordering a higher royalty in certain situations. ${ }^{135}$ Other flaws in the law include restriction in lists of drugs that may be subject to compulsory licensing for export, two-year period for the production of the generic drugs and need to seek permission from patent holders before exporting manufactured generic drugs. ${ }^{136}$

A practical challenge in invoking the provision of the Canadian law occurred recently when MSF in May of 2004 placed an order under this law to supply drugs to one of its fields project in a developing country. This required MSF to locate a local generic manufacturing company within Canada. ${ }^{137}$ After a long search MSF was able to locate Apotex a generic pharmaceutical company which agreed to produce a three-in-one antiretroviral combination of zidovudine, lamivudine and nevirapine (AZT $+3 \mathrm{TC}+\mathrm{NVP})$, drugs which represent one of the first-line treatment regimens for HIV recommended by the WHO. Apotex had to develop a fixed-dose combination of these drugs to simplify treatment for those in need. When this was done it required the Canadian legislature to amend the schedule to the new patent law, since the new fixed-dose combination was not included in the schedule of drugs qualified to be exported in the legislation. This took some time before it was done sometimes in September 2005. When this hurdle was crossed it became necessary for Apotex in 2006 to negotiate with the company holding the patent over the proposed drugs to be

134. This Agreement was launched in January 1994 with Canada, Mexico and the US as parties to the Agreement. It established one of the world's largest free trade areas.

135. Canadian HIV/AIDS Legal Network, 'Global Access to Treatment: Canada's Bill c-9 and the Compulsory Licensing of Pharmaceuticals for Export to Countries of Need', available at <www.aidslaw.ca/Maincontent/issues/cts/patent-amend/billC-9flyer300604.pdf> (accessed on 6 June 2007).

136. R. Elliott, 'TRIPS from Doha to Cancun ... to Ottawa: Global Development in Access to Treatment and Canada Bill C-56', 8 Canadian HIV/AIDS Law Policy Review (2003) p. 1. Originally the now Bill C-9 was known as Bill C-56.

137. R. Elliot, 'Will They Deliver Treatment Access?: WTO Rules and Canada's Law on Generic Medicine Exports', 11 Canadian HIV/AIDS Law Policy Review (2006) p. 13. 
exported under compulsory licensing. Apotex was only able to get the go-ahead from the patient holder sometime in August of 2007. This clearly exemplifies the difficulty which may be encountered in successfully invoking use of compulsory licensing even under the Canadian legislation. An indication that the recently adopted amendment of the TRIPS Agreement, which is based on the August 2003 Decision of the Council for TRIPS, will likely hinder access to life-saving drugs for people in poor countries.

Similarly, India has recently introduced an amendment to its patent law in compliance with its TRIPS obligation. ${ }^{138}$ Prior to this amendment, the Indian Patent Act of 1970 completely prohibited patent product for medicines. This has in turn served as one of the major incentives for the growth of a strong generic pharmaceutical industry in that country. ${ }^{139}$ During the early years of development in India up to the time the Patent Act was passed in 1970 the pharmaceutical industry witnessed a relatively small growth accounting for just 25 percent of the domestic market. However, the restriction on product patent, prices and foreign investment triggered a rapid development of the industry which now accounts for up to 70 percent of the domestic market meeting nearly all the demands for formulations. ${ }^{140}$ A significant consequence of this development in the generic pharmaceutical industry is the lower prices of drugs in India compared to other countries of the world. While prices of drugs in India were one of the highest in the world at the early age of development, they are today one of the cheapest. ${ }^{141}$

But with the coming into existence of a new law in early 2005 patent product for medicines is now protected in India. ${ }^{142}$ Under the new law, generic drugs discovered prior to 1995 are exempted from patent protection. However, drugs produced after this year will be subject to patent protection in line with Article 70(8) and (9) of TRIPS. The Indian government prior to this law had created the so-called mail box applications for patent. This implies that these applications were already on the waiting line before 2005 when India complied with her obligations under TRIPS by recognising patents for pharmaceuticals. The implication of this is that in the event that any of these applications is granted, generic manufacturer of such drugs will have to pay a reasonable amount as royalty to the patent holder. This portion of the Act which fails to explain what will amount to a reasonable royalty has been criticised for being vague and

138. The Patents (Amendment) Act (Bill 32-C of 2005) of India.

139. J.O. Lanjouw, 'The Introduction of Pharmaceutical patent in India: Heartless Exploitation of the Poor and Suffering?', NBER Working Paper (Cambridge, MA, NBER 1998) p. 24.

140. Government of India, Department of Chemicals and Petrochemicals, 'Annual Report (1999-2000)', available at <chemicals.nic.in/annrep99.htm>.

141. S. Chandhri, 'The Evolution of Indian Pharmaceutical Industry', in G. Frelker, et al., eds, The Pharmaceutical Industry in India and Hungary: Policies, Institutions and Technological Development (Washington, DC, World Bank 1997) p. 6.

142. See The Patents (Amendment) Act, supra n. 114. 
subject to controversy. ${ }^{143}$ It has been suggested that between 3 to 4 percent royalty be adopted in conformity with international norms. ${ }^{144}$ There are fears already being expressed in many African countries that this law may likely hinder access to cheaper drugs in future.

It is significant to note that this new law provides for the issuance of compulsory licensing to export to a country with insufficient capacity, provided that country through notification allowed such importation. This is no doubt a welcome development, however; the viability of this provision is yet to be ascertained in view of December 2005 amendment of the TRIPS Agreement. ${ }^{145}$

\section{HUMAN RIGHTS AND INTELLECTUAL PROPERTY RIGHTS}

One emerging debate in the international human rights arena has to do with the relationship between intellectual property rights and states' obligation under human right treaties. This is particularly important when one considers the fact that intellectual property rights is also recognised under human rights instruments. Notable among these instruments are the UDHR and the ICESCR. Article 27(1) of the UDHR provides: 'Every one has the right to the material protection of the moral and material interests resulting from any scientific, literary, or artistic production of which he is the author.' Article 15 of the ICESCR also recognises the right of everyone to take part in the cultural life, to enjoy the benefits of scientific progress and its application and to benefit from the protection of the moral and material interests resulting from any scientific, literary or artistic production of which he/she is the author.

It would seem from these provisions that these instruments seek to strike a balance between interest of the public to benefit from technology and that of the inventor of the technology. This would obviously require a human rights approach. Such an approach, as suggested by Chapman, should be 'predicated on the centrality of protecting and nurturing human dignity and the common good'. ${ }^{146}$ The goal is to improve human welfare and not to maximize economic benefits. ${ }^{147}$ In other words, 'from a human rights perspective, intellectual property protection is understood more as a social product with a social function and not primarily as an economic relationship'. ${ }^{148}$

143. G. Crues, 'India: New Patent Law May Restrict Access to HIV/AIDS Treatment', $10 \mathrm{Ca}$ nadian HIVIAIDS Legal Network Policy and Review (2005) p. 28.

144. MSF, 'The Beginning of the End of Affordable Generics', 22 March 2005, available at $<$ www.accessmed-msf.org/prod/publications.asp?scntid=2232005174897\&contenttype $>$ (accessed on 7 June 2007).

145. See Section 55 amending Section 92 of the original Act.

146. A.R. Chapman, 'The Human Rights Implications of Intellectual Property Protection', 5 Journal of International Economic Law (2002) p. 861 at p. 867.

147. Ibid., at p. 868.

148. Ibid. 
This observation further receives support from the history of the drafting of these instruments. A critical examination of the events leading to the eventual drafting of the two articles in the two human rights instruments mentioned above reveal that basic human rights documents never intended to recognise interests of authors or inventors as fundamental human rights. ${ }^{149}$ For instance, the original Article 27 of the UDHR never contained a second paragraph. ${ }^{150}$ It was based on the suggestion by Mexico that this paragraph was included. Mexico had argued for additional rights to the one already protected under the 1948 Bogota Declaration. ${ }^{151}$ This was to be for the benefit of intellectual workers, scientist or writer, so that all forms of work - manual and intellectual - will receive same protection. ${ }^{152}$ The introduction of intellectual property rights was intended to serve as a sort of discouragement to greedy activities of foreign publishing houses. Statements of many countries during the debates concerning this article revealed that the clause was merely analysed from a copyright perspective only. ${ }^{153}$

Similarly, sub-paragraph (c) of Article 15(1) was not part of the original draft Covenant of 1954 which merely contained two paragraphs - (a) and (b). Therefore, Article 15(1)(c) must be seen as an addition to this particular Article and should not be accorded preference over the first two sub-paragraphs. ${ }^{154}$ In actual fact, Article 15(1)(c) only refers to 'authors' an indication that its addition to the original Article 15(1) - sponsored by Costa Rica and Uruguay - was to protect authors against improper action on the part of publishers. ${ }^{155}$ It was never intended to qualify the two preceding sub-paragraphs, but merely to highlight a particular challenge. ${ }^{156}$ Commenting on this provision, Hestermeyer has argued that it was never the intention of the ICESCR to elevate intellectual property law to a status of a human right. ${ }^{157} \mathrm{He}$ argues further that, assuming that Article $15(1)(c)$ creates a fundamental rights at all, this would not apply to 'patents' or

149. UN Sub-Commission on the Promotion and Protection of Human Rights, Globalization and Its Impact on the Full Enjoyment of All Human Rights, Res. 2001/5 (15 August 2001), UN Doc. E/CN.4/Sub.2/Res/2001/5.

150. See UN, Report of the 3rd Session of the Commission on Human Rights, UN Doc. E/800 (1948).

151. See Art. 13 of the American Declaration on the Rights and Duties of Man, OEA/Ser.L.V/ II.82 doc.6 rev.1 (1948), UN, Draft International Declaration of Human Rights - Mexico Amendment to Article 25 of the Draft Declaration, UN Doc. A/C.3/266 (1948) note that Art. 27 of ICCPR used to be Art. 25 in the original draft.

152. UN Third Committee Summary Records of Meetings, UN Doc. A/C.3/SR.799 (1957).

153. See, for example, Statement of Dominican Republic supporting the amendment, UN Doc. A/C.3/SR.799 (1957), India which abstained, UN Doc. A/C.3/SR.798 (1957).

154. Cullet, supra n. 31, at p. 150.

155. See Draft International Covenant on Human Rights, Report of the 3rd Committee, UN Doc. A/3764 (1957).

156. Cullet, supra n. 31, at p. 150 .

157. H. Hestermeyer, Human Rights and the WTO: The Case of Patents and Access to Medicines (Oxford, Oxford University Press 2007) p. 154. 
'copyrights' neither will it apply to pharmaceutical companies since the Article adopts words such as 'everyone', 'author' or 'he' an indication that it was meant specifically to protect individuals. ${ }^{158}$ This appears to coincide with the position of the Committee on CESCR in its General Comment $17 .{ }^{159}$ Furthermore, the Committee has urged States Parties to strike an adequate balance between their obligations under Article 15(1)(c) and other rights guaranteed under the Covenant. ${ }^{160}$ It reasons that in doing so, the private interests of authors should not be unduly favoured but rather preference should be given to public interest.

Arising from the above, since both the UDHR and the ICESCR recognise the right of every one to benefit from cultural life and scientific development, it would seem to be that the right of an individual author is secondary to that of the society in balancing of priorities. ${ }^{161}$ Thus, the focus of human rights instruments is on societal benefits, while intellectual property places emphasis on individual's rights and protection. Therefore, neither the UDHR nor the ICESCR can be invoked by pharmaceutical companies to justify hindrance to access to life-saving medications in Africa. ${ }^{162}$ On the whole, a major difference exists between intellectual property rights and human rights. While the former are temporary rights granted by the state and subject to revocation by same, the latter are inalienable and timeless. ${ }^{163}$

Under international law there is a growing consensus of the primacy of international human rights laws over other treaties. This is evident in the Vienna Programme of Action where it was agreed that the protection and promotion of human rights 'is the first responsibility of governments' ${ }^{164}$ This appears to be a reaffirmation of Article 1(3) of the UN Charter which is to the effect that one of the purposes of the UN shall be to strive towards 'promoting and encouraging respect for human rights and for fundamental freedoms for all'. ${ }^{165}$ Besides, Article 103 of the UN Charter provides that '[i]n event of a conflict between the obligations of the Members of the United Nations under the present Charter and their obligations under any other international agreement, their obligations under the present Charter shall prevail'. ${ }^{166}$ Under the Vienna Law of Treaties it

158. Ibid.

159. UN Committee on Economic, Social and Cultural Rights, The Right of Everyone to Benefit from the Protection of the Moral and Material Interests Resulting from any Scientific, Literary or Artistic Production of Which he or she is the Author, General Comment No. 17 (2005), UN Doc. E/C.12/GC/17 (12 January 2006), para. 7.

160. Ibid., para. 35 .

161. Cullet, supra n. 31, at p. 152.

162. Hestermeyer, supra n. 157 , at p. 158.

163. Human Rights and Intellectual Property: Statement of the Committee on Economic, Social and Cultural Rights; Follow up to the discussion on Article 15, UN Doc. E/C.12/2001/15 (26 November 2001).

164. Vienna Programme of Action, supra n. 19, Part 1, Art. 1.

165. Charter of the United Nations, 26 June 1945 (entered into force 24 October 1945), TS 67 (1946).

166. Ibid. 
is provided that the determination of states' rights and obligations pursuant to their treaties are 'subject to Article 103 of the Charter of the United Nations'. ${ }^{167}$ The International Court of Justice (ICJ) has addressed this issue in the Aerial Incident over Lockerbie case. ${ }^{168}$ In that case, the ICJ rejected the argument of Libya that, under the Montreal Convention for the Suppression of Unlawful Acts Against the Safety of Civil Aviation, it was entitled to choose domestic prosecution over extradition of those accused of the airplane bombing in question. Rather the ICJ ruled that the UN Charter (Art. 25) requires UN member states to carry out the decisions of the Security Council, and this Charter obligation prevailed over the provisions of the Montreal Convention. Thus, Libya was legally required to comply with the UN Security Council's resolution requiring extradition of the accused. One may conclude, therefore, that since all the members of WTO are members of the UN, which is founded on respect for human rights - and most have ratified different human rights treaties - their obligations under the latter supercede the former.

It has been observed that even though the right to health does not constitute a non-derogable right under international law, if a hierarchy was to be established between human rights and intellectual property rights; it is most likely that the former would take precedence over the latter. ${ }^{169}$ Forman similarly notes that no parity exists in the nature of human rights to essential medicines and intellectual property rights, since the latter are better understood as legal entitlements than as fundamental rights. ${ }^{170}$ She further argues that the human rights of the most vulnerable and the poor should be prioritised when they conflict with trade and intellectual property interest. ${ }^{171}$ Whilst Hestermeyer would not admit that human rights law is of a higher normative level than the WTO regime, he submits that it is of a higher appeal than WTO law. ${ }^{172}$ However, he was quick to add that the strong enforcement nature of human rights seems to put WTO law on a higher level in a factual hierarchy of regimes, 'so that ultimately state behaviour will largely be determined by the solution found within the WTO regime'. ${ }^{173}$ However, the UN Sub Commission on the Promotion and Protection of Human Rights has lent its voice to this issue. It has urged states to 'ensure that the implementation of the TRIPS Agreement does not negatively impact on the enjoyment of human rights as provided for in international human rights

167. Vienna Convention on Law of Treaties, entered into force on 27 January 1980, 1155 UNTS p. 331, 8 ILM p. 679.

168. Order of 14 April 1992 (regarding Request for Indication of Provisional Measures), ICJ Reports (1992) p. 3, para. 42.

169. Cullet, supra n. 31.

170. L. Forman, 'Trade Rules, Intellectual Property and the Right to Health', 21 Ethics and International Affair (2007) p. 337 at p. 347.

171. Ibid.

172. Hestermeyer, supra n. 157, at p. 206.

173. Ibid. 
instruments by which they are bound' ${ }^{174}$ It particularly reminds governments of the need to give primacy to obligations under human rights treaties over economic policies or any other international agreements

This area of the law, however, remains unsettled. This certainly calls for urgent attention and clarification in the international law arena. But the Committee on CESCR has urged States Parties to the Covenant to always bear in mind their obligations under international human rights law - particularly the Covenant - when ratifying other treaties relating to trade. The Committee has further noted recently that states' obligations under Article 15(1)(c) of the Covenant should not constitute impediments to fulfilling their core obligations in relation to right to health and that states have the duty 'to prevent unreasonably high cost for access to essential medicines' ${ }^{175}$

\section{CONCLUSION}

While the above-mentioned developments in the use of compulsory licensing are welcomed they have not by any means resolved the problem on the use of compulsory licensing. The recent amendment to the TRIPS Agreement which should have provided an opportunity for members of the WTO to explicitly address the problem posed by use of compulsory licensing, fails to meet the aspiration of the people in developing countries in dire need of life-saving drugs. The amendment as it stands merely reinforces insensitivity and cynicism on the part of developed countries with regard to ensuring access to life-saving medicines for people in poor regions. It is of great concern, that the historic Declaration at Doha is being undermined by the negative attitudes of developed countries to the use of compulsory licensing. This is prejudicial to the interest of Africans who are in dire need of life-saving medications.

The high mortality rate for HIV/AIDS every year in Africa is particularly worrisome. While infected people in the developed world have been able to mitigate the impact of the epidemic through use of ARVs, the same cannot be said of their counter parts in Africa who lack access to these drugs due to high cost. This merely exemplifies the gross inequities that exist between the north and the south. Although the TRIPS in its principles and objectives clearly set out to correct these inequities, its actual implementation has failed to do this. As pointed out by UNDP '[a] single set of minimum rules may seem to create level playing field, since one set of rules applies to all. But as currently practiced the game is not fair because the players are of such unequal strength economically and institutionally. ${ }^{176}$ The August 2003 Decision of the Council for TRIPS and

174. UN Sub-Commission on the Promotion and Protection of Human Rights, supra n. 149.

175. General Comment 17, supra n. 159, para. 35.

176. UNDP, Human Development Report: Making Technologies Work for Human Development (New York, UNDP 2001) p. 7. 
the December 2005 amendment of the TRIPS Agreement in response to paragraph 6 of Doha are in the least very disappointing. The Council should have done better than this. As shown in this article a practical implementation of both Decision and the amendment may indeed pose serious problems for intending nation seeking to invoke the use of compulsory licensing. This can be described as nothing but a Greek gift.

It may be contended that developed countries and pharmaceutical companies both have the duty under international law to ensure that their actions do not by any means hinder access to medicines for those in poor countries of the world. ${ }^{177}$ Indeed, the Committee on CESCR in its General Comment 14 does observe that 'States parties have an obligation to ensure that their actions as members of international organizations take due account of the right to health'. ${ }^{178}$ The Committee similarly urges non-state actors to ensure that their activities do not in any way impede the enjoyment of the right to health. The UN Millennium Development Goals in goal number 8 also call for cooperation between developed countries and developing countries in eradicating poverty in the world. This cooperation can similarly apply to ensuring access to life-saving medications for people in poor regions as Africa. Since a correlation exists between poor health and poverty. As rightly pointed out by the Special Rapporteur on the right to health 'international assistance and cooperation require that all those in a position to assist should, first, refrain from acts that make it more difficult for the poor to realize their right to health and, second, take measures to remove obstacles that impede the poor's realization of the right to health'. ${ }^{179}$

177. See A. Buchaman and M. Decamp, 'Responsibility for Global Health', 27 Theoretical Medicine and Bioethics (2006) p. 95 at p. 110.

178. General Comment 14, supra n. 13, para. 39.

179. See the Preliminary Report of Paul Hunt, Special Rapporteur on the Right of Everyone to the Highest Attainable Standard of Physical and Mental Health, to the Fifty-Ninth Session of the UN General Assembly, UN Doc. A/59/422 (2004), para. 33. 